Revista Brasil. Bot., V.33, n.1, p.93-105, jan.-mar. 2010

\title{
Multiple dormancy and maternal effect on Miconia ferruginata (Melastomataceae) seed germination, Serra de Caldas Novas, Goiás, Brazil
}

\author{
CLESNAN MENDES-RODRIGUES ${ }^{1}$, FRANCIELLE PAULINA DE ARAÚJO², \\ CLÁUDIA BARBOSA-SOUZA ${ }^{1,3}$, VALÉRIA BARBOSA-SOUZA ${ }^{1}$, MARLI A. RANAL ${ }^{1,5}$, \\ DENISE GARCIA DE SANTANA ${ }^{4}$ and PAULO EUGENIO OLIVEIRA ${ }^{1}$
}

(received: February 07, 2008; accepted: January 13, 2010)

\begin{abstract}
Multiple dormancy and maternal effect on Miconia ferruginata (Melastomataceae) seed germination, Serra de Caldas Novas, Goiás, Brazil). Species with mostly asexual reproduction are interesting subjects for germination studies since variation would be more easily linked to environmental factors. Miconia ferruginata DC. is an apomictic treelet in Brazilian cerrado areas on rocky outcrops. Germination of seeds collected from individuals occurring in the Serra de Caldas Novas State Park, Goiás, was studied in three experiments under controlled conditions. Germination characteristics differed among individuals and were correlated with altitude and soil Al content. Seeds from plants growing at lower altitudes, with lower soil aluminium content, presented malformed seeds with absence of embryo which rendered lower, but better synchronized germination. The nested analysis showed that from the total variance, $78.14 \%$ for germinability, $54.56 \%$ for uncertainty of the germination process, and $68.30 \%$ for the quantity of seeds without embryo was attributed to the altitudinal effect. Individuals nested within altitude contributed up to $16.93 \%$ for the total variance. It means that there is low variability among individuals of the same altitude and high variability among individuals from different points of the slope, making clear that for the studied population the environmental effect is stronger than the genetic component to determine the seed quality. The testa of the seeds provides a mechanical dormancy which seems to be associated also with phenolic compounds, which help to disperse germination through time. Photoblastism was also registered for seeds of this species.
\end{abstract}

Key words - altitudinal gradient, campo rupestre, cerrado, dormancy, tropical savanna

RESUMO - (Dormência múltipla e efeito maternal na germinação de sementes de Miconia ferruginata (Melastomataceae), Serra de Caldas Novas, Goiás, Brasil). Espécies com reprodução principalmente assexuada são interessantes para estudos de germinação, uma vez que a variação pode ser mais facilmente associada a fatores ambientais. Miconia ferruginata DC. é um arbusto apomítico de cerrado rupestre brasileiro. A germinação de sementes coletadas no Parque Estadual da Serra de Caldas Novas, Goiás foi estudada em três experimentos sob condições de laboratório. O processo de germinação diferiu entre os indivíduos, correlacionando-se com altitude e teor de Al do solo. Sementes oriundas de plantas crescendo nas menores altitudes, com menor teor de alumínio no solo, apresentaram sementes mal formadas, com ausência de embrião, resultando em baixa germinabilidade, mas maior sincronia de germinação. A análise hierárquica mostrou que $78,14 \%$ da variabilidade na germinabilidade, $54,56 \%$ na incerteza e $68,30 \%$ na quantidade de sementes sem embrião foram atribuídos ao efeito altitudinal. Indivíduos agrupados dentro de altitude contribuíram até $16,93 \%$ para a variância total. Isto significa que há baixa variabilidade entre indivíduos da mesma altitude e alta variabilidade entre indivíduos de diferentes pontos da Serra, indicando que para a população estudada o efeito ambiental é mais forte do que o componente genético para determinar a qualidade das sementes. A testa das sementes propiciou dormência mecânica que parece estar associada com a presença de compostos fenólicos, o que ajuda a dispersar a germinação no tempo. Fotoblastismo também foi registrado para sementes dessa espécie.

Palavras-chave - campo rupestre, cerrado, dormência, gradiente altitudinal, savana tropical

\section{Introduction}

Melastomataceae comprises 166 genera and 4500 species (Clausing \& Renner 2001). More than two thirds

\footnotetext{
1. Universidade Federal de Uberlândia, Instituto de Biologia, Caixa Postal 593, 38400-902 Uberlândia, MG, Brazil.

2. Universidade Estadual de Campinas, Ecologia, Caixa Postal 6109, 13083-970 Campinas, SP, Brazil.

3. In memorian

4. Universidade Federal de Uberlândia, Instituto de Ciências Agrárias, Caixa Postal 593, 38400-902 Uberlândia, MG, Brazil.

5. Corresponding author: ranal@ufu.br
}

of these species occur in Central and South America, which makes this family a predominantly Neotropical group (Ellison et al. 1993). This is the sixth largest family in the Brazilian flora, with 68 genera and more than 1500 species distributed from the Amazon to the frontier with Uruguay, in every plant physiognomy (Romero \& Martins 2002).

Many Melastomataceae produce a great number of small seeds in fleshy berries, with endozoochorous dispersal by birds (Ellison et al. 1993, Manhães et al. 2003). Endozoochory usually involves the presence of a resistant seed coat, imposing a physical and/or 
mechanical dormancy sensu Nikolaeva (Baskin \& Baskin 1998), and the ability to build up soil seed banks (Pereira-Diniz \& Ranal 2006).

Miconia ferruginata DC. is a polycarpic perennial shrub (up to 2-3 m height), occurring in Bolivia and in the Cerrado region of Brazil, mainly on rocky outcrops (campo rupestre), but also in other Cerrado physiognomies (Romero \& Martins 2002). It is common in cerrado (stricto sensu) and campos rupestres of the Serra de Caldas Novas, Goiás, Brazil, flowering mainly from April to July and setting seeds from June to August, although it is possible to find flowering and fruiting individuals most of the year. Despite this long flowering period and high fruit set, no visitor was ever observed on its flowers and further analysis showed the species is apomictic, producing autonomously a great number of fleshy, bird-dispersed berries (Santos (2003) and further field observations since then), as reported for other species of the tribe Miconieae (Goldenberg \& Shepherd 1998). Since pollen viability is very low, ca. $8 \%$ according to Santos (2003), and pollen is withheld in poricidal anthers, fruit and seed production is mostly asexual.

Apomixis may lead to clonal populations (Martins $\&$ Oliveira 2003). As a consequence, genetic variability in these populations is probably low and due mostly to much more rare mutations. Genetic variation, natural intraspecific polymorphism (Venable 1984) and maternal effects (Roach \& Wulff 1987) have been viewed as problems for plant ecology, evolutionary, and genetic studies since they require special attention related to experimental design, statistical procedures to separate genetic from non-genetic effects, and result interpretation. Maternal effects are sources of error in the sense that they are non-Mendelian and reduce the precision of genetic studies (Roach \& Wulff 1987). Besides, environmental maternal effects can increase the amount of environmental noise and thus making slow the response to selection (Roach \& Wulff 1987). In this sense, investigations using species with mostly asexual reproduction and lower genetic variability than truly sexual species can be a promising source of information to evaluate the weight of the environmental component on the intrapopulation variation. Seed samples collected from these plants would render, in theory, less variability, providing an excellent material for germination studies. They would permit to detect, for example, environmental effects on the physiological quality of seeds, although within-individual variation could occurs as observed for Taraxacum apomicts biotypes (Tweney \& Mogie 1999).

Thus, the present study aimed to (1) characterize the germination of freshly collected seeds of Miconia ferruginata from a population in the Serra de Caldas Novas State Park, Goiás, Brazil, based on their capacity, rate, and synchrony. Since biogeography of dormancy types is still poorly known for seeds of Melastomataceae, the aim of this study was also (2) to investigate the presence and class of dormancy in the seeds of this species. The quantification of the variance attributed to the environmental conditions and the variance attributed to the individuals (3) were also object of investigation.

\section{Material and methods}

Seed collection - Mature fruits of Miconia ferruginata (ca. 200 dark purple berries per maternal plant) were collected in a cerrado rupestre area (sensu Ribeiro \& Walter 1998), on rocky outcrops of the Serra de Caldas Novas State Park (PESCAN), Caldas Novas, Goiás, Brazil. The region is characterized by an Aw climate according to the Köppen (1948) system, with marked seasonality, having a rainy summer from October to March and a dry winter from April to September. The average rainfall is around $1500 \mathrm{~mm}$ and temperatures ranges from 20 to $25^{\circ} \mathrm{C}$ during the warmer months (Almeida \& Sarmento 1998).

Mature fruits were randomly collected from 10 individuals occurring along the road to access the upper part of the Park, on 28 September 2003 (table 1). The declivity between the extreme sites $\left(7.65^{\circ}\right)$ resulted in an altitudinal gradient of $110 \mathrm{~m}$ between the first and last collection site. Fruits were mashed and washed to take out the seeds which were stored during 6 days in paper bags at room temperature (between 25 and $30^{\circ} \mathrm{C}$ ), in a dry chamber containing silica gel with humidity indicator. A second collection of seeds was made on 13 October 2004, at three collection sites (1)

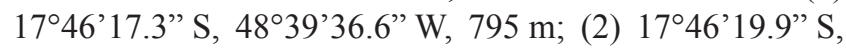
$48^{\circ} 39^{\prime} 45.5^{\prime \prime} \mathrm{W}, 833 \mathrm{~m}$; and (3) $17^{\circ} 46^{\prime} 29.6^{\prime \prime} \mathrm{S}, 48^{\circ} 40^{\prime} 00.8^{\prime \prime} \mathrm{W}$, $907 \mathrm{~m}$. Seeds were collected from three individuals of each site, and the distance between each plant was 2 to $5 \mathrm{~m}$. Only the larger and apparently viable seeds were used in the experiments. Seventy mature fruits collected at random from 10 individuals were used to count seeds in order to plan the experiments. Fruits presented $24.73 \pm 4.36$ seeds, $50 \%$ of them large and well formed which were used for the experiments.

Intrapopulational variation on seed germination - Seeds of Miconia ferruginata collected in September 2003 were sown on filter paper, in plastic transparent humid chambers with distilled water (Emanueli chamber, patent number PI0520543-3, INPI - Instituto Nacional da Propriedade Industrial), and kept in a germination chamber at $25.7^{\circ} \mathrm{C}$, under continuous fluorescent white lamps $\left(12.1 \pm 5.1 \mu \mathrm{mol} \mathrm{m}^{-2} \mathrm{~s}^{-1}\right.$ of photosyntetically active radiation). The experimental design was completely randomized, with four replicates of 50 seeds per mother plant. One additional treatment was constituted 
Table 1. Miconia ferruginata (Melastomataceae) seed site collections in the Serra de Caldas Novas State Park, GO, Brazil, in September 2003.

\begin{tabular}{cccccc}
\hline Individual & South & West & $\begin{array}{c}\text { Altitude } \\
(\mathrm{m})\end{array}$ & $\begin{array}{c}\text { Slope }^{1} \\
\left({ }^{\circ}\right)\end{array}$ & $\begin{array}{c}\text { Distance }^{1} \\
(\mathrm{~m})\end{array}$ \\
\hline 1 & $1^{\circ} 46^{\prime} 17.3^{\prime \prime}$ & $48^{\circ} 39^{\prime} 36.6^{\prime \prime}$ & 795 & - & - \\
2 & $1^{\circ} 46^{\prime} 18.8^{\prime \prime}$ & $48^{\circ} 39^{\prime} 40.0^{\prime \prime}$ & 807 & 6.16 & 111.22 \\
3 & $1^{\circ} 46^{\prime} 19.1^{\prime \prime}$ & $48^{\circ} 39^{\prime} 42.0^{\prime \prime}$ & 813 & 5.71 & 59.98 \\
4 & $1^{\circ} 46^{\prime} 19.4^{\prime \prime}$ & $48^{\circ} 39^{\prime} 43.0^{\prime \prime}$ & 821 & 14.01 & 32.06 \\
5 & $17^{\circ} 46^{\prime} 20.5^{\prime \prime}$ & $48^{\circ} 39^{\prime} 45.5^{\prime \prime}$ & 834 & 9.00 & 82.06 \\
6 & $1^{\circ} 46^{\prime} 21.8^{\prime \prime}$ & $48^{\circ} 39^{\prime} 49.0^{\prime \prime}$ & 852 & 9.09 & 112.52 \\
7 & $1^{\circ} 46^{\prime} 23.1^{\prime \prime}$ & $48^{\circ} 39^{\prime} 51.1^{\prime \prime}$ & 861 & 6.95 & 73.80 \\
8 & $1^{\circ} 46^{\prime} 24.1^{\prime \prime}$ & $48^{\circ} 39^{\prime} 53.5^{\prime \prime}$ & 876 & 10.81 & 78.52 \\
9 & $1^{\circ} 46^{\prime} 26.2^{\prime \prime}$ & $48^{\circ} 39^{\prime} 56.8^{\prime \prime}$ & 893 & 8.22 & 117.74 \\
10 & $1^{\circ} 46^{\prime} 30.2^{\prime \prime}$ & $48^{\circ} 40^{\prime} 00.9^{\prime \prime}$ & 905 & 3.97 & 172.95 \\
\hline
\end{tabular}

${ }^{1}$ Between collection places, one in relation to its predecessor.

by a compound seed sample, using seeds in equal parts from 10 mother plants. Germination was recorded daily, with removal of germinated seeds. At the $4^{\text {th }}, 8^{\text {th }}, 15^{\text {th }}$, and $33^{\text {rd }}$ days after sowing, filter papers were changed and the asepsis of the seeds were made with nystatin suspension $(10,000$ units nystatin per $\mathrm{mL}$ in DPBS - Dulbecco's Phosphate Buffered Saline; $1 \mathrm{~mL}$ per $100 \mathrm{~mL}$ of distilled water). Germination criterion was the protrusion of any part of the embryo.

Germinability $(G)$, mean germination time $(\bar{t})$, coefficient of variation of the germination time $\left(C V_{t}\right)$, mean germination rate $(\bar{v})$, uncertainty associated to the distribution of the relative frequency of germination $(U)$, and synchronization index $(Z)$ were calculated (see papers where these expressions were presented for the first time, intermediate calculus, the sense and applications of these measurements in Santana \& Ranal (2004) and Ranal \& Santana (2006)).

Analysis of variance and Tukey test for pairwise comparisons were used for germinability due to the normally distributed residuals (Shapiro-Wilk test) and homoscedasticity (Levene's test). For the other germination measurements, with different distribution and/or heteroscedasticity, Kruskal-Wallis and Dunn's tests were used. For the statistical assumptions and for the other statistical tests 0.01 and 0.05 of significance were adopted, respectively.

Simple linear correlations (Pearson correlation) between germination measurements and altitude were made using the residuals of the measurements to standardize the effect of treatment (Santana \& Ranal 2006) and tested using the Student's $t$ test at 0.01 of significance. The adjectives to describe the magnitude of the correlations were used according to Davis (1971).

Seeds of the second collection (October 2004) were prepared, sown, observed, and evaluated as were the seeds of the first collection. The experimental design was also completely randomized, including seeds of nine individuals of Miconia ferruginata, three of each altitude, and four replications of 50 seeds $\left(25.5^{\circ} \mathrm{C}\right.$ and $12.5 \pm 6.6 \mu \mathrm{mol} \mathrm{m}{ }^{-2} \mathrm{~s}^{-1}$ of PAR - Photosynthetic Active Radiance). Besides ANOVA and Tukey test, data were submitted to the nested analysis, according to Neter et al. (1985), to quantify the variance components related to the effect of altitude $\left(\sigma_{A}^{2}\right)$, individuals nested within altitude $\left[\sigma_{I / A}^{2}\right]$, and the residual component $\left(\sigma^{2}\right)$.

Photoblastism and seed dormancy - Seeds of Miconia ferruginata were sown on filter paper and maintained in humid chambers (Emanueli chamber) under the action of (1) sodium hypochlorite with $0.14 \%$ of active chlorine for a soft scarification, (2) cytokinin at $10 \mu \mathrm{g} \mathrm{mL}^{-1}$, (3) $\mathrm{KNO}_{3}$ at $0.2 \%$, (4) gibberellic acid $\left(\mathrm{GA}_{3}\right)$ at $10 \mu \mathrm{g} \mathrm{mL}^{-1}$, and (5) water as control. A sixth treatment was kept in water and in darkness. The experiment was carried out in the same germination chamber as in the first experiment described $\left(25.7^{\circ} \mathrm{C}\right.$ and $11.65 \pm 5.64 \mu \mathrm{mol} \mathrm{m}^{-2} \mathrm{~s}^{-1}$ of PAR), where the samples were distributed randomly. Each treatment was constituted by only one sample of 100 seeds, 10 of them from each mother plant collected in September 2003. Data collection, germination criterion and seed asepsis were carried out as in the first experiment, except for the sample kept in darkness, which was examined only on the $60^{\text {th }}$ day after sowing.

For the germination measurements with unknown variances, but estimated by sample values, as is the case of germinability, mean germination time and rate, and the uncertainty of the germination process, the samples of the experiment were compared by the Student's $t$ test for heterogeneous variances. Two germinabilities were compared using the conventional comparisons between proportions, described by Snedecor \& Cochran (1989).

Permeability and phenolic compounds of seed coats - Using dry and intact seeds stored in paper bags with silica gel for 12 months at $25-30{ }^{\circ} \mathrm{C}$, imbibition was evaluated during $48 \mathrm{~h}$ for two samples of 20 seeds proceeding from each mother 
plant (September 2003 collection). Seeds were maintained over filter paper saturated with distilled water, at $25^{\circ} \mathrm{C}$. The quantity of seed water during the imbibition process was calculated according to the expression used by Baskin et al. (1998). Samples of 10 seeds of the 10 mother plants of the same collection date were immersed in $10 \%$ iron chloride solution to detect the presence of phenolic compounds in the seed coats and the first area stained by this solution, supposing this area is more permeable to water.

Soil sample analysis - Samples of soil were collected on 13 October 2004 in the 10 points where the seeds of Miconia ferruginata were firstly collected. Five samples per plot, collected under the crown of the mother plants, from zero to $10 \mathrm{~cm}$ depth, were mix-up to compose the soil samples submitted to physical and chemical analysis. The soil $\mathrm{pH}$ was measured in water $(1: 2.5)$; organic material was determined by the Walkley \& Black's method; P, K, Fe, Mn, Zn, and $\mathrm{Cu}$ available by Mehlich-1; $\mathrm{Ca}, \mathrm{Mg}$, and $\mathrm{Al}$ estimated in $1 \mathrm{M} \mathrm{KCl}$ and the quantity of soil cations was determined by atomic absorption spectrophotometry and P by colorimetry (Allen 1974).

Simple linear correlations (Pearson correlation) were calculated to detect associations between the chemical and physical soil composition, germinability, and altitude and were tested using the Student's $t$ test at 0.01 and 0.05 of significance.

Seed sample analysis - Four samples of seeds were also submitted to chemical analysis, including seeds of the individuals 1 and 9, collected in September 2003; seeds of four individuals collected in October 2004; and seeds of 20 individuals collected in July 2007.

\section{Results}

Intrapopulational variation on seed germination - The initial and final germination time of Miconia ferruginata seeds collected in September 2003 ranged from 7 to 45 days. Germinability increased along the altitudinal gradient with higher values registered between 876 and $905 \mathrm{~m}$ (table 2). For the other germination measurements no statistical differences were detected due to the high variability among seeds of the same mother plant, especially when collected below $861 \mathrm{~m}$ altitude. The seed mixture included in the experimental design presented intermediate behaviour in relation to that of isolated individuals.

Positive and very high linear correlations between altitude and $G, C V_{\text {t }}$, and $U$, and $r$ values non significant between altitude and $\bar{t}$ and $\bar{v}$ indicated that ascending the altitudinal gradient, seeds had higher germinability, higher uncertainty and higher dispersion around the mean time, without variation in time and rate of germination (table 3). The $r$ values also pointed out that slower seeds have the germination process more spread through time (see correlations between $\bar{t}$ and $Z, \bar{v}$ and $Z, \bar{t}$ and $C V_{\mathrm{t}}, \bar{v}$ and $C V_{\mathrm{t}}$ in the table 3 ) than faster seeds.

Seed germination behaviour for the October 2004 collection was similar to that of seeds from the first collection, i.e., seeds from the higher altitude sites had higher germinability in relation to the others. The germination process of the seeds of higher altitude sites presented higher uncertainty, spreading germination through time (table 4). Germination started 5 days after sowing and lasted up to 45 days. Percentage of seeds without embryos decreased significantly with an increase in altitude (table 4).

The nested analysis showed $78.14 \%$ of the variance due to the altitudinal effect and $8.41 \%$ due to the individuals within the same altitude, for germinability (table 5). Higher variance as a consequence of the altitude was also registered for the uncertainty of the germination process $(54.56 \%)$ and for the percentage of seeds without embryo (68.30\%). For the other four germination measurements the variance component attributed to the residual was higher than altitude and individuals nested within altitude. The contribution of the individuals nested within altitude for the variance was low, up to $16.93 \%$.

Photoblastism and seed dormancy - Seeds of Miconia ferruginata are photoblastic, with 38\% germination when exposed to continuous light (table 6) and no germination in darkness. Germination, in this experiment, started 8 days after sowing and lasted up to 38 days. No significant differences were found between the different treatments exposed to continuous light in terms of germinability and uncertainty (table 6). Mean germination time of seeds exposed to sodium hypochlorite and cytokinin increased significantly and, as a consequence, germination rate decreased in these treatments, when compared with the others. Results show lower dispersion around the mean time (low $C V_{\mathrm{t}}$ value), but lower synchrony of the germination process (high $Z$ value) for seeds of the control, in relation to the other treatments. Seeds of all treatments had low germinability, slow, and asynchronous germination.

Permeability and phenolic compounds of seed coats - Seed mass for nine of the samples studied in the altitudinal gradient decreased $2.5 \mathrm{~h}$ from sowing, indicating loss of mass during the imbibition process (table 7). Only seeds collected from the individual at the lowest altitude showed increment of mass after the same period of time. Loss of seed material during imbibition 
Revista Brasil. Bot., V.33, n.1, p.93-105, jan.-mar. 2010

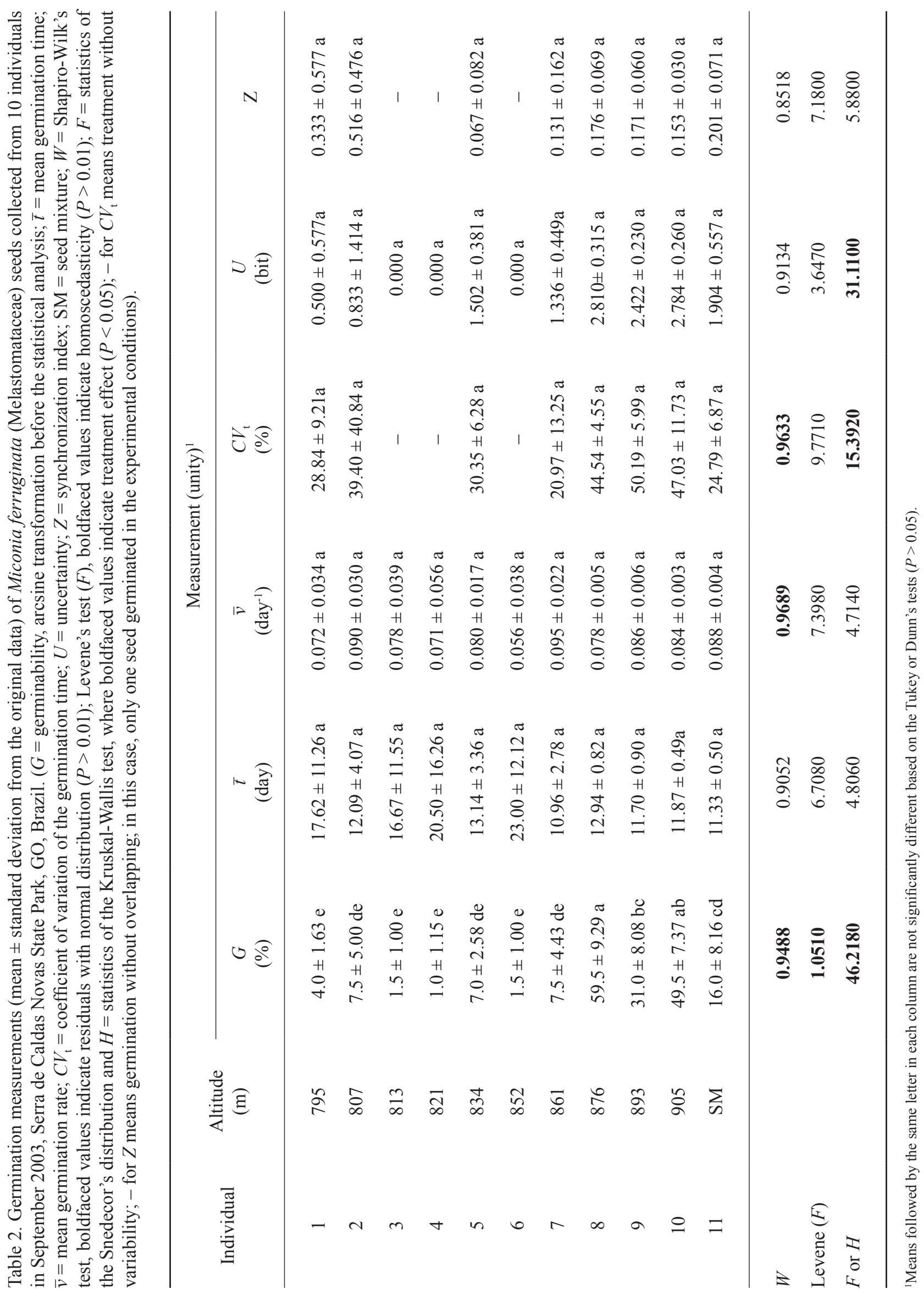


Table 3. Coefficients of the linear correlation $(r)$ between altitude and germination measurements of Miconia ferruginata seeds (Melastomataceae), Serra de Caldas Novas State Park, GO, Brazil. Seeds collected in September 2003. ( $G=$ germinability; $\bar{t}=$ mean germination time; $\bar{v}=$ mean germination rate; $C V_{\mathrm{t}}=$ coefficient of variation of the germination time; $U=$ uncertainty; $Z=$ synchronization index; $r=0.01$ to 0.09 negligible; $r=0.10$ to 0.29 low; $r=0.30$ to 0.49 moderate; $r=0.50$ to 0.69 substantial; $r=0.70$ to 0.99 very high; and $r=1.0$ perfect correlation (Davis 1971)).

\begin{tabular}{ccccccc}
\hline \multirow{2}{*}{ Measurement } & \multicolumn{5}{c}{ Measurement } & \multirow{2}{*}{ Altitude } \\
\cline { 2 - 5 } & $\bar{t}$ & $\bar{v}$ & \multicolumn{1}{c}{$C V_{\mathrm{t}}$} & $U$ & \multicolumn{1}{c}{$Z$} \\
\hline $\mathrm{n}$ & -0.064 & 0.080 & 0.175 & $0.464^{* *}$ & -0.061 & $0.770^{* *}$ \\
$\bar{t}$ & & $-0.938^{* *}$ & $0.589^{* *}$ & -0.013 & $-0.433^{* *}$ & -0.298 \\
$\bar{v}$ & & & $-0.732^{* *}$ & -0.108 & $0.539^{* *}$ & 0.330 \\
$C V_{\mathrm{t}}$ & & & $0.483^{* *}$ & $-0.499^{* *}$ & $0.766^{* *}$ \\
$U$ & & & & $-0.701^{* *}$ & $0.802^{* *}$ \\
$Z$ & & & & & -0.093 \\
\hline
\end{tabular}

${ }^{* *}$ Significant at 0.01 of probability by Student's $t$ test.

Table 4. Germination measurements and percentage of seeds without embryo of Miconia ferruginata (Melastomataceae) collected from nine individuals in October 2004, Serra de Caldas Novas State Park, GO, Brazil. For percentage of seeds without embryo arcsine transformation were applied before the statistical analysis. ( $G=$ germinability; $\bar{t}=$ mean germination time; $\bar{v}=$ mean germination rate; $C V_{\mathrm{t}}=$ coefficient of variation of the germination time (arcsine transformation before the statistical analysis); $U=$ uncertainty; $Z=$ synchronization index; $W=$ Shapiro-Wilk's test, boldfaced values indicate residuals with normal distribution $(P>0.01)$; Levene's test $(F)$, boldfaced values indicate homoscedasticity $(P>0.01) ; F=$ statistics of the Snedecor's distribution, where boldfaced values indicate treatment effect $(P<0.05)$; - for $C V_{\mathrm{t}}$ means treatment without variability; - for $Z$ means germination without overlapping, that is, only one seed germinated or some seeds germinated, each one at each observation time but in only one replication).

\begin{tabular}{|c|c|c|c|c|c|c|c|c|}
\hline \multirow{2}{*}{ Individual } & \multirow{2}{*}{$\begin{array}{l}\text { Altitude } \\
\text { (m) }\end{array}$} & \multicolumn{6}{|c|}{ Measurement (unity) ${ }^{1}$} & \multirow{2}{*}{$\begin{array}{l}\text { Seeds without } \\
\text { embryo }(\%)^{1}\end{array}$} \\
\hline & & $G(\%)$ & $\bar{t}(\mathrm{dia})$ & $\bar{v}\left(\operatorname{dia}^{-1}\right)$ & $C V_{\mathrm{t}}(\%)$ & $U$ (bit) & $Z$ & \\
\hline 1 & 795 & $8.0 \mathrm{~cd}$ & $12.18 \mathrm{ab}$ & $0.081 \mathrm{a}$ & $46.55 \mathrm{a}$ & $1.54 \mathrm{abc}$ & $0.083 \mathrm{a}$ & $88.0 \mathrm{~b}$ \\
\hline 2 & 795 & $5.5 \mathrm{~d}$ & $11.69 \mathrm{ab}$ & $0.088 \mathrm{a}$ & $39.08 \mathrm{a}$ & $1.10 \mathrm{ab}$ & - & $93.0 \mathrm{ab}$ \\
\hline 3 & 795 & $1.0 \mathrm{~cd}$ & $9.50 \mathrm{a}$ & $0.108 \mathrm{a}$ & - & $0 \mathrm{a}$ & - & $99.0 \mathrm{a}$ \\
\hline 4 & 833 & $8.0 \mathrm{~cd}$ & $15.98 \mathrm{~b}$ & $0.062 \mathrm{a}$ & $35.84 \mathrm{a}$ & $1.43 \mathrm{abc}$ & - & $87.0 \mathrm{bc}$ \\
\hline 5 & 833 & $10.5 \mathrm{~cd}$ & $12.98 \mathrm{ab}$ & $0.079 \mathrm{a}$ & $18.48 \mathrm{a}$ & $1.70 \mathrm{bcd}$ & $0.184 \mathrm{a}$ & $82.0 \mathrm{bcd}$ \\
\hline 6 & 833 & $19.0 \mathrm{bc}$ & $14.86 \mathrm{ab}$ & $0.068 \mathrm{a}$ & $32.94 \mathrm{a}$ & $2.53 \mathrm{~cd}$ & $0.105 \mathrm{a}$ & $81.0 \mathrm{bcd}$ \\
\hline 7 & 907 & $34.5 \mathrm{a}$ & $12.46 \mathrm{ab}$ & $0.081 \mathrm{a}$ & $39.82 \mathrm{a}$ & $3.02 \mathrm{~d}$ & $0.093 \mathrm{a}$ & $48.5 \mathrm{e}$ \\
\hline 8 & 907 & $25.0 \mathrm{ab}$ & $13.87 \mathrm{ab}$ & $0.072 \mathrm{a}$ & $41.55 \mathrm{a}$ & $2.57 \mathrm{~cd}$ & $0.115 \mathrm{a}$ & $73.5 \mathrm{~cd}$ \\
\hline 9 & 907 & $29.0 \mathrm{ab}$ & $13.07 \mathrm{ab}$ & $0.078 \mathrm{a}$ & $40.47 \mathrm{a}$ & $2.66 \mathrm{~cd}$ & $0.135 \mathrm{a}$ & $65.5 \mathrm{~d}$ \\
\hline$W$ & & 0.9799 & 0.9738 & 0.9726 & 0.9745 & 0.9466 & 0.9549 & 0.9668 \\
\hline Levene $(F)$ & & 1.997 & 1.638 & 3.704 & 2.227 & 2.266 & 0.981 & 1.381 \\
\hline$F$ & & 20.937 & 2.837 & 3.042 & 1.822 & 8.211 & 0.827 & 21.358 \\
\hline
\end{tabular}

${ }^{1}$ Means followed by the same letter in each column are not significantly different based on the Tukey test $(P>0.05)$.

was easily visible because a droplet of ferrugineous liquid was formed near the raphal side and the filter paper was also marked during imbibition with the same ferrugineous colour. In the second evaluation, $8.5 \mathrm{~h}$ after sowing, seeds of all individuals showed an increase of mass, indicating integument permeability and water income. Mass increments from 59.3 to $482.6 \%$ were registered $48 \mathrm{~h}$ after the first evaluation (table 7). The lowest increase in seed mass was registered for seeds of the individual at the lowest altitude. 
Table 5. Variance components $(\%)$ related to the effect of altitude $\left(\sigma_{A}^{2}\right)$, individuals nested within altitude $\left[\left(\sigma_{I / A}^{2}\right]\right.$, and to the residual $\left(\sigma^{2}\right)$ for seeds of Miconia ferruginata (Melastomataceae) collected in October 2004, Serra de Caldas Novas State Park, GO, Brazil. ( $G=$ germinability; $\bar{t}=$ mean germination time; $\bar{v}=$ mean germination rate; $C V_{\mathrm{t}}=$ coefficient of variation of the germination time; $U=$ uncertainty; $Z=$ synchronization index. PSWE = percentage of seeds without embryo).

\begin{tabular}{lrrrrrrr}
\hline & \multicolumn{7}{c}{ Measurement } \\
\cline { 2 - 8 } Source of variation & \multicolumn{1}{c}{$G$} & $\bar{t}$ & $\bar{v}$ & $C V_{\mathrm{t}}$ & $U$ & $Z$ & PSWE \\
\cline { 2 - 8 } & & \multicolumn{7}{c}{$(\%)$} \\
\hline Altitude & 78.14 & 24.68 & 25.66 & 18.86 & 54.56 & 1.41 & 68.30 \\
Individual (Altitude) & 8.41 & 12.88 & 14.30 & 0.00 & 16.39 & 0.00 & 16.93 \\
Residual & 13.45 & 62.44 & 60.03 & 81.14 & 29.05 & 98.59 & 14.77 \\
\hline
\end{tabular}

Table 6. Germination measurements of Miconia ferruginata (Melastomataceae) seeds collected at Serra de Caldas Novas State Park, GO, Brazil, in September 2003, and submitted to growth regulators and sodium hypochlorite. $(G=$ germinability; $\bar{t}=$ mean germination time; $\bar{v}=$ mean germination rate; $C V_{\mathrm{t}}=$ coefficient of variation of the germination time; $U=$ uncertainty; $Z=$ synchronization index).

\begin{tabular}{lccccc}
\hline \multirow{2}{*}{$\begin{array}{l}\text { Measurement } \\
\text { (unity) }\end{array}$} & \multicolumn{5}{c}{ Treatment $^{1}$} \\
\cline { 2 - 5 } & $\mathrm{NaClO}^{2}$ & $\begin{array}{c}\text { Cytokinin } \\
\mathrm{KNO}_{3}{ }^{3}\end{array}$ & $\begin{array}{c}\mathrm{GA}_{3}{ }^{4} \\
10 \mu \mathrm{mL}^{-1}\end{array}$ & $\begin{array}{c}\text { Water } \\
\text { (under light) }\end{array}$ \\
\hline$G(\%)$ & $0.4 \%$ & $10 \mu \mathrm{g} \mathrm{mL}{ }^{-1}$ & $0.2 \%$ & $32.0 \mathrm{a}$ & $38.0 \mathrm{a}$ \\
$\bar{C}$ (day) & $26.0 \mathrm{a}$ & $34.0 \mathrm{a}$ & $34.0 \mathrm{a}$ & $11.88 \mathrm{a}$ & $11.21 \mathrm{a}$ \\
$C V_{t}(\%)$ & $13.54 \mathrm{~b}$ & $13.35 \mathrm{~b}$ & $12.00 \mathrm{a}$ & 49.09 & 32.51 \\
$\bar{v}$ (day $)$ & 57.50 & 47.06 & 33.72 & $0.084 \mathrm{a}$ & $0.089 \mathrm{a}$ \\
$Z$ & $0.074 \mathrm{~b}$ & $0.075 \mathrm{~b}$ & $0.083 \mathrm{a}$ & 0.183 & 0.333 \\
$U$ (bit) & 0.154 & 0.184 & 0.125 & $2.311 \mathrm{a}$ & $2.035 \mathrm{a}$ \\
\hline
\end{tabular}

${ }^{1}$ Means followed by the same letter in each line are not significantly different based on the Student's $t$ test; ${ }^{2}$ Sodium hypochlorite; ${ }^{3}$ Potassium nitrate; ${ }^{4}$ Gibberellic acid.

Table 7. Mean mass of Miconia ferruginata (Melastomataceae) seeds before imbibition and increment or decrease mass (\%) during the imbibition process. Seeds collected in September 2003, at Serra de Caldas Novas State Park, GO, Brazil.

\begin{tabular}{cccc}
\hline Individual & $\begin{array}{c}\text { Mass }(\mathrm{g}) \\
\text { before } \\
\text { imbibition }\end{array}$ & $\begin{array}{c}\text { Increment or } \\
\text { decrease after } \\
2.5 \mathrm{~h} \text { from } \\
\text { sowing }(\%)^{1}\end{array}$ & $\begin{array}{c}\text { Increment } \\
\text { after } 48 \mathrm{~h} \text { from } \\
\text { sowing }(\%)^{2}\end{array}$ \\
\hline 1 & 0.00695 & $\mathbf{3 6 . 4 4}$ & 59.26 \\
2 & 0.00985 & 10.53 & 105.68 \\
3 & 0.00940 & 17.85 & 96.50 \\
4 & 0.00795 & 44.68 & 182.50 \\
5 & 0.00775 & 60.03 & 213.23 \\
6 & 0.00765 & 68.38 & 278.95 \\
7 & 0.00730 & 79.60 & 482.62 \\
8 & 0.01085 & 58.57 & 187.80 \\
9 & 0.01350 & 31.58 & 74.82 \\
10 & 0.01070 & 65.59 & 347.93 \\
\hline
\end{tabular}

${ }^{1}$ Increment (boldfaced value) or decrease in the seed mass; ${ }^{2}$ Calculus based on the mass registered $2.5 \mathrm{~h}$ after sowing.
Results of the test using iron chloride indicated that water intake occurs through the raphal region, whose outer side became soft and black stained after approximately $1.5 \mathrm{~h}$ of imbibition, also indicating the presence of phenolic compounds in this part of the testa. After $24 \mathrm{~h}$ the seed coat was completely stained.

Chemical and physical composition of the soil - Soil samples collected showed medium to high acidity and low fertility (table 8). There was a negative and substantial correlation between altitude and $\mathrm{pH}$, but no significant association between $\mathrm{pH}$ and germinability (table 9). On the other hand, positive and very high correlations were registered between aluminium content and aluminium saturation, altitude, and germinability, showing that ascending the gradient, the quantity of aluminium increases together with seed germinability. These correlations show that the germinability is associated with soil aluminium content, but is not associated with soil $\mathrm{pH}$. Another significant, positive, and very high correlation between germinability and 


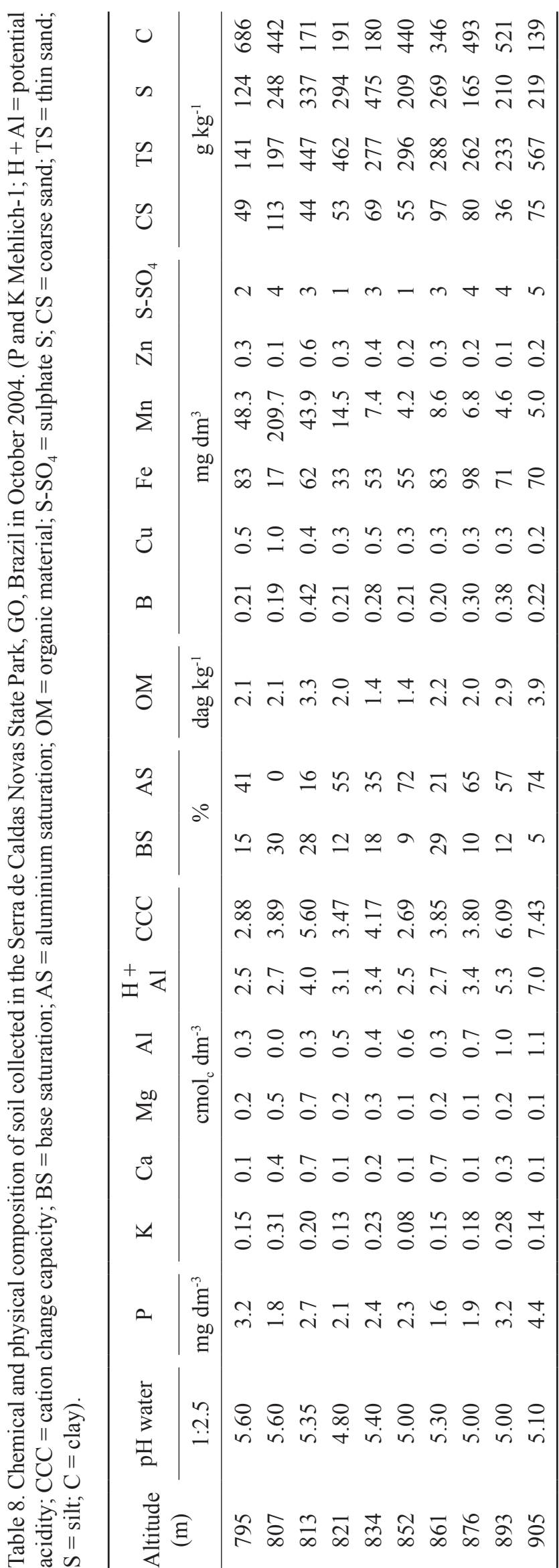

chemical characteristics of the soil was detected for sulphate (table 9).

Chemical composition of the seeds - Seeds of Miconia ferruginata present higher quantity of aluminium than the micronutrients (table 10). Among the macronutrients, nitrogen predominates and among the micronutrients, iron and manganese appear in higher quantity in relation to the other. Seeds produced at the lower part of the slope have lower quantity of nitrogen, sulphur, and zinc in relation to the seeds produced in the upper part.

\section{Discussion}

Low germinability, slow, and asynchronous germination are indicative of seed dormancy. As low germinability is also related to low viability, these two aspects will be analysed. Two different types of dormancy seem to be associated to the seeds of Miconia ferruginata; a mechanical dormancy sensu Nikolaeva (Baskin \& Baskin 1998), due to the thickness of the testa, which restricts embryo growth, and a chemical dormancy due to phenols present in the raphal part of the testa, both of them related to slow and asynchronous germination.

Seeds of Miconia ferruginata present features which are typical of the Melastomataceae and of the genus Miconia in particular, such as the exotesta differentiated into a mechanical sclerotic layer, while in the raphal part, the mechanical layer is derived from the endotesta (Groenendijk et al. 1996). Thus, the mechanical sclerotic layers appear to be the principal cause of the mechanical dormancy. There are few records of physical or mechanical dormancy in Melastomataceae, although other types of dormancy are present in this family, as physiological dormancy recorded for seeds of Mouriri myrtilloides M. Gomez (Garwood 1983) and Rhexia mariana L. var. interior (Pennell) Kral \& Bostick (Baskin et al. 1999). Mechanical dormancy was only registered in Clidemia hirta (L.) D. Don (Pereira-Diniz 2003).

The rate of imbibition corroborates the idea of mechanical dormancy for seeds of this species. After the water intake, there is a reactivation of the embryo metabolism and during 9 to 23 days a slow enzymatic hydrolysis of the testa compounds occurs, making the testa soft enough to allow embryo protrusion. This softening process is marked at the connection between the raphal and testal part of the seed, where the embryo protrusion occurs. This intra-seminal development pattern and dormancy are important since they help to spread germination through time, allowing germination of part of the seeds during the rainy season just after 
Table 9. Coefficients of the linear correlation $(r)$ between germinability of Miconia ferruginata (Melastomataceae) seeds, altitude, and soil characteristics. $(G=$ germinability; $\mathrm{H}+\mathrm{Al}=$ potential acidity; $\mathrm{CCC}=$ cation change capacity; $\mathrm{BS}=$ base saturation; $\mathrm{AS}=$ aluminium saturation; $\mathrm{OM}=$ organic material; $\mathrm{S}_{-} \mathrm{SO}_{4}=$ sulphate $\mathrm{S} ; \mathrm{CS}=$ coarse sand; $\mathrm{TS}=$ thin sand).

\begin{tabular}{lccccccccccc}
\hline \multirow{2}{*}{$G$} & $\mathrm{pH}$ & $\mathrm{P}$ & $\mathrm{K}$ & $\mathrm{Al}$ & $\mathrm{Ca}$ & $\mathrm{Mg}$ & $\mathrm{H}+\mathrm{Al}$ & $\mathrm{CCC}$ & $\mathrm{BS}$ & $\mathrm{AS}$ & $\mathrm{OM}$ \\
\cline { 2 - 11 } altitude & -0.360 & 0.360 & 0.080 & $0.706^{*}$ & -0.336 & -0.459 & $0.628^{*}$ & 0.513 & -0.532 & 0.534 & 0.416 \\
& $-0.581^{*}$ & 0.377 & -0.090 & $0.868^{* *}$ & -0.166 & $-0.583^{*}$ & $0.705^{*}$ & $0.595^{*}$ & -0.542 & $0.635^{*}$ & 0.404 \\
& $\mathrm{~B}$ & $\mathrm{Cu}$ & $\mathrm{Fe}$ & $\mathrm{Mn}$ & $\mathrm{Zn}$ & $\mathrm{S}^{-\mathrm{SO}_{4}}$ & $\mathrm{CS}$ & $\mathrm{TS}$ & $\mathrm{Silt}$ & $\mathrm{Clay}$ \\
$G$ & 0.180 & -0.360 & 0.533 & -0.261 & -0.428 & $0.724^{* *}$ & 0.133 & 0.181 & -0.382 & 0.056 \\
altitude & 0.155 & $-0.629^{*}$ & 0.456 & -0.536 & -0.439 & 0.541 & -0.001 & 0.328 & -0.190 & -0.134 \\
\hline
\end{tabular}

${ }^{*} P<0.05$ and ${ }^{* *} P<0.01$ for Student's $t$ test.

Table 10. Chemical composition of Miconia ferruginata (Melastomataceae) seeds collected in the Serra de Caldas Novas State Park, GO, Brazil, compared to the chemical composition of leaf samples. (Sample 1 = seeds of the mother plant number 1, collected in September 2003; Sample $2=$ seeds of the mother plant number 9 collected at the same date; Sample $3=$ seeds of four mother plants collected in October 2004; Sample 4 = seeds of 20 mother plants collected in July 2007. M.a. = Miconia albicans, M.p. = Miconia pohliana, M.f. = Miconia ferruginata species growing in a dystrophic soil of cerradão in Brasília, DF, Brazil (Haridasan \& Araújo 1988); wd = without determination; tr = trace of the nutrient).

\begin{tabular}{|c|c|c|c|c|c|c|c|c|c|c|c|}
\hline \multirow{2}{*}{ Seed sample } & $\mathrm{N}$ & $\mathrm{P}$ & $\mathrm{K}$ & $\mathrm{Ca}$ & $\mathrm{Mg}$ & $\mathrm{S}$ & $\mathrm{Al}$ & $\mathrm{Cu}$ & $\mathrm{Fe}$ & $\mathrm{Mn}$ & $\mathrm{Zn}$ \\
\hline & \multicolumn{6}{|c|}{$\mathrm{g} \mathrm{Kg}^{-1}$} & \multicolumn{5}{|c|}{$m g \mathrm{Kg}^{-1}$} \\
\hline 1 & 9.8 & 1.4 & 6.0 & 2.3 & 1.0 & 0.7 & 610.0 & 12.0 & 78.0 & 188.0 & 17.0 \\
\hline 2 & 14.4 & 1.5 & 7.0 & 2.4 & 1.2 & 1.5 & 790.0 & 14.0 & 150.0 & 109.0 & 26.0 \\
\hline 3 & 17.5 & 1.2 & 5.5 & 2.9 & 1.0 & 1.5 & 610.0 & 7.0 & 74.0 & 133.0 & 21.0 \\
\hline 4 & 16.8 & 1.3 & 7.0 & 2.0 & 1.2 & 1.6 & 680.0 & 13.0 & 88.0 & 42.0 & 21.0 \\
\hline \multicolumn{12}{|l|}{ Foliar sample } \\
\hline M.a. & wd & wd & 3.4 & 3.3 & 1.1 & wd & 6250.0 & 10.0 & 50.0 & 50.0 & 30.0 \\
\hline M.f. & wd & wd & 1.6 & 4.5 & 2.0 & wd & 3750.0 & $\operatorname{tr}$ & 160.0 & 240.0 & 20.0 \\
\hline M.p. & wd & wd & 1.8 & 1.7 & 0.8 & wd & 1560.0 & $\operatorname{tr}$ & 50.0 & 20.0 & 10.0 \\
\hline
\end{tabular}

dispersion. It is possible to say that seeds of this species have relative dormancy sensu Labouriau (1983), caused by mechanical and chemical blockade.

Seed coat dormancy and the consequent slow, asynchronous, and irregular germination pattern may be adaptive features in the specific growing condition of steep rocky outcrops with shallow soils and loose pebbles. In these areas, dispersed seeds may be carried away by the rains many times before settling on a proper place for establishment. Kept in the soil after dispersal and dislodgment, seeds can be viable for longer periods in a dynamic seed bank from which recruitment can occur for different growing seasons as recorded for several species in temperate regions (Egley 1995, Baskin et al. 1998).

Photoblastism and mechanical resistant testa also allow Miconia ferruginata to build persistent seed bank as in Clidemia hirta (Pereira-Diniz 2003) and Rhexia mariana var. interior with photoblastic seeds (Baskin et al. 1999). Persistent seed banks are also common in other Melastomataceae of gallery forests in the Cerrado region as Miconia calvescens DC. and M. theaezans (Bonpl.) Cogn. (Pereira-Diniz \& Ranal 2006). Photoblastism seems to be a common feature in this family (Queiroz 1983, Andrade 1995, Vieira et al. 1996, Zaia \& Takaki 1998, Válio \& Scarpa 2001).

Initial loss of seed mass during the imbibition process increased with altitude. Since germinability also increases with altitude and mean germination time decreases in the same direction, it is possible to think that the loss of mass is related to loss of phenolic compounds, breaking the chemical dormancy.

A possible consequence of the occurrence of a species in different altitudes is that the seed coat became 
thicker and contained more polyphenols with increasing elevation, reflecting their action as germination reducer as was suggested by Roach \& Wulff (1987). According to the authors, garden experiments show that changing plants to different elevations, seed coat inhibition can be induced, suggesting that variation in germination requirements can be environmentally induced, but the importance of this fact to within-population variation in seed dormancy is not clear because few studies have been done in natural populations. For Miconia ferruginata, washing of the seeds could be essential for the germination. There are records suggesting that phenolic compounds may act as a protection against herbivores, fungus, bacteria, and virus infections, since phenols can inhibit enzyme activity of these organisms, as well as contributing to seed integument resistance against mechanical damage, light, and imbibition (Werker 1997). Actually, the role of phenolic compounds and their impact on plant development, reproduction and defense have been better understood over the past few decades (Buchanan et al. 2000).

Morphological dormancy sensu Nikolaeva (Baskin \& Baskin 1998) were not detected for seeds of Miconia ferruginata since embryo is well formed at the end of the development of viable seeds. Physiological dormancy was also absent because gibberellic acid and $\mathrm{KNO}_{3}$ did not modify the germination process in relation to the control treatment. Perhaps the $\mathrm{GA}_{3}$ concentration applied to the seeds was not sufficient to break the inhibition caused by the phenols present in the testa. The decrease in germinability for seeds under the action of sodium hypochlorite probably was a consequence of a moderate chemical scarification of the weaker part of the seeds, affecting embryo tissues. This is another proof of the testa permeability, at least in the connection between the raphal and the other part of the seed coat. Diaspores sensitivity to this substance was tested by several authors (Carnelossi et al. 1995).

Besides the mechanical and chemical blockage to germination process, the studied population of Miconia ferruginata showed lower seed viability, due to absence of embryo, for individuals at the base of the slope than for those at the top of the gradient. This would explain the low germinability and also other characteristics as the low increment of mass during the imbibition process, for seeds from the lowest altitudes. Low germinability due to lack of embryo was also reported for Tibouchina granulosa Cogn., with 15\% germination and T. pulchra Cogn., with 30\% germination (Zaia \& Takaki 1998).

Above $54.6 \%$ of the variability on the germinability, uncertainty of the germination process, and seeds without embryo for the Miconia ferruginata population was explained by the environmental conditions or non-genetic effects. The decrease in the germinability in the lower altitude environments was a direct consequence of the embryoless seeds formed in this part of the studied gradient. This behaviour can be included in one class of maternal effects. There are different classes of these effects, each one having a different evolutionary consequence, including cytoplasmic maternal effects, endosperm dosage maternal effects, and phenotypic maternal effects that can be either genetic or environmental (Roach \& Wulff 1987). According to the authors, the use of clonal individuals growing in different environments is an appropriate technique to separate the genetic from the environmental effects. As M. ferruginata may naturally form clonal populations due to its apomictic characteristic and low pollen viability, the observed differences can be mostly the result of environmental effect.

Altitudinal gradients determine changes on temperature, air and soil moisture, lighting, wind speed, depth and nature of the soils and these differences can influence plant development, seed production and germination (Baskin \& Baskin 1998, Ofir \& Kigel 2003). Significant effects on seeds were detected between sea level and $2500 \mathrm{~m}$ in Saudi Arabia (Abulfatih 1995) and between 1600 and $3400 \mathrm{~m}$ in the Andes (Cavieres \& Arroyo 2000), much greater altitudinal gradients than the $100 \mathrm{~m}$ or so encountered in Caldas Novas. In any case, altitudinal effect on seed quality and germination of Miconia ferruginata may restrict species distribution and would explain its occurrence on higher areas of the Serra de Caldas Novas. The distribution of tree species in Central Brazilian deciduous dry forests, as Myracrodruon urundeuva Allemão and Tabebuia roseo-alba (Ridl.) Sandwith is influenced by small soil topographic gradients, in slopes ranging from 5 to $12.1^{\circ}$ and altitudes ranging from 365.1 to $372.1 \mathrm{~m}$ (Oliveira-Filho et al. 1998). According to the authors, the topographic and soil depth gradients affect the soil water content and, as a consequence, the species distribution.

This altitudinal effect on the germination of Miconia ferruginata seeds appears to be linked to soil conditions. The soil of the PESCAN can be included in the lithic ustorthent dystrophic soil type, according to the Brazilian Soil Classification System (Brasil 1999) and the soil aluminium content was associated with higher altitudes and higher germinabilities, and could be an important factor to explain germination variability for the studied population. As for other Miconia species of Cerrado (Haridasan \& Araújo 1988) and Melastoma malabathricum L. (Watanabe \& Osaki 2001, Watanabe 
et al. 2005), M. ferruginata is an Al-accumulator, storing more than $1000 \mathrm{mg} \mathrm{kg}^{-1}$ of aluminium (Weeb (1954) criterion; see table 10) in the leaves (Haridasan \& Araújo 1988). Although there is no information about the influence of aluminium on seed ontogeny, several Al-accumulator species have their vegetative growth as a function of soil aluminium content (Haridasan \& Araújo 1988, Watanabe \& Osaki 2001, Watanabe et al. 2005) and it is known that the plant nutritional status may affect fruit and seed production. Several studies have shown that lower aluminium levels in the soil have detrimental effects on Al-accumulators, similar to aluminium toxicity to non-accumulating plants (Johnson et al. 1997, Watanabe et al. 2005). For M. ferruginata the embryo production appears to be affected by the soil aluminium content although other factors could also be associated.

Seeds of Miconia ferruginata have higher quantity of potassium and copper in relation to the leaves of the same species, and have higher quantity of iron and manganese then leaves of Miconia albicans (Sw.) Triana and M. pohliana Cogn. (see data extracted of Haridasan \& Araújo 1988 and included in table 10). There is no information about the limits of the aluminium content in the mother plant tissues to permit the seed formation, neither if this mineral is important to the seed germination.

The last important point is to answer if a mixed sample of seeds collected from different mother plants can represent the population. Comparing the seed behaviour from September 2003, seeds produced from 795 to $861 \mathrm{~m}$ had less than $8 \%$ of germinability, while seeds produced from 876 to $905 \mathrm{~m}$ had germinability above $31 \%$, forming two groups. When equal parts of seeds were mixed to study the effects of germination regulators and sodium hypochlorite, the germinability ranged from 26 to $38 \%$, without significant differences among treatments due to the high variability caused by differences among seeds. This is the critical point of the germination experiments. Plants with malformed seeds, with germinability below $8 \%$, underestimate and plants with well formed and viable seeds, with germinability above $31 \%$, overestimate the general mean of the seed sample studied, increasing the variability within each treatment. Important differences associated to embryo production and seed quality as environment answers disappeared when mixed samples were analysed. It means that to mix seeds produced by several plants in one sample is a decision that needs to be associated to previous experiments. If the range of values is high among mother plants, the answer of the seed mix sample will not represent the population, because the values of the characteristics will be under or overestimated. The strong environmental action on the Miconia ferruginata seed quality due to the altitudinal gradient, evaluated by individual seed samples would be negligible if mix samples had been studied.

In conclusion, the germinability is lower for seeds of Miconia ferruginata produced at the base of the slope due to the absence of embryo and one of the factors related to this absence may be the low aluminium content of the soil. The germination process is slow, asynchronous, and spread through time due to the mechanical and chemical dormancy, resulting in a relative dormancy. Although probably of apomictic origin, the seeds presented high variability associated with the altitudinal gradient.

Acknowledgements - The authors thank to the Direction of the Serra de Caldas Novas State Park for the permission for seed and soil collections; to the Capes for a MSc grant to the first author; to Dr. Fábio R. Scarano and Dr. Carol Baskin for the important suggestions which improved the manuscript; and to Edivane Cardoso for the help to transform GPS data into slope and distance measurements.

\section{References}

ABULFATIH, H.A. 1995. Seed germination in Acacia species and their relation to altitudinal gradient in south-western Saudi Arabia. Journal of Arid Environments 31:171178.

ALMEIDA, A.F. \& SARMENTO, F.N.M. (coord.). 1998. Parque Estadual da Serra de Caldas: plano de manejo. Centro Tecnológico de Engenharia Ltda., Fundação Estadual do Meio Ambiente, Goiânia.

ALLEN, S.E. 1974. Chemical analysis of ecological materials. Blackwell Scientific Publications, Oxford.

ANDRADE, A.C.S. 1995. Efeito da luz e da temperatura na germinação de Leandra breviflora Cogn., Tibouchina benthamiana Cogn., Tibouchina grandifolia Cogn. e Tibouchina moricandiana (DC.) Baill. (Melastomataceae). Revista Brasileira de Sementes 17:29-35.

BASKIN, C.C. \& BASKIN, J.M. 1998. Seeds: ecology, biogeography, and evolution of dormancy and germination. Academic Press, San Diego.

BASKIN, C.C., BASKIN, J.M. \& CHESTER, E.W. 1999. Seed dormancy and germination in Rhexia mariana var. interior (Melastomataceae) and eco-evolutionary implications. Canadian Journal of Botany 77:488-493.

BASKIN, J.M., NAN, X. \& BASKIN, C.C. 1998. A comparative study of seed dormancy and germination in an annual and a perennial species of Senna (Fabaceae). Seed Science Research 8:501-512. 
BRASIL. 1999. Sistema brasileiro de classificação de solos. Embrapa, Serviço de Produção de Informação, Brasília.

BUCHANAN, B.B., GRUISSEM, W. \& JONES, R.L. 2000. Biochemistry and molecular biology of plants. American Society of Plant Physiology, Rockville, Maryland.

CARNELOSSI, M.A.G., LAMOUNIER, L. \& RANAL, M.A. 1995. Efeito da luz, hipoclorito de sódio, escarificação e estratificação na germinação de sementes de alface (Lactuca sativa L.), cv. Maioba e Moreninha-deUberlândia. Pesquisa Agropecuária Brasileira 30:779787.

CAVIERES, L.A. \& ARROYO, M.T.K. 2000. Seed germination response to cold stratification period and termal regime in Phacelia secunda (Hydrophyllaceae). Plant Ecology 149:1-8.

CLAUSING, G. \& RENNER, S.S. 2001. Molecular phylogenetics of Melastomataceae and Memecylaceae: implications for character evolution. American Journal of Botany 88:486-498.

DAVIS, J.A. 1971. Elementary survey analysis. PrenticeHall, Englewood.

EGLEY, G.H. 1995. Seed germination in soil: dormancy cycles. In Seed development and germination (J. Kigel \& G. Galili, eds.). Marcel Dekker, New York, p.529-543.

ELLISON, A.M., DENSLOW, J.S., LOISELLE, B.A. \& BRENÉS, M.D. 1993. Seed and seedling ecology of Neotropical Melastomataceae. Ecology 74:1733-1749.

GARWOOD, N.C. 1983. Seed germination in a seasonal tropical forest in Panama: a community study. Ecological Monograph 53:159-181.

GOLDENBERG, R. \& SHEPHERD, G.J. 1998. Studies on the reproductive biology of Melastomataceae in "cerrado" vegetation. Plant Systematics and Evolution 211:13-29.

GROENENDIJK, J.P., BOUMAN, F. \& CLEEF, A.M. 1996. An exploratory study on seed morphology of Miconia Ruiz \& Pavón (Melastomataceae), with taxonomic and ecological implications. Acta Botanica Neerlandica 45:323-344.

HARIDASAN, M. \& ARAÚJO, G.M. 1988. Aluminiumaccumulating species in two forest communities in the Cerrado region of Central Brazil. Forest Ecology and Management 24:15-26.

JOHNSON, E.L., CAMPBELL, T.A. \& FOY, C.D. 1997. Effect of soil $\mathrm{pH}$ on mineral element concentrations of two Erythroxylum species. Journal of Plant Nutrition and Soil Science 20:1503-1515.

KÖPPEN, W. 1948. Climatología: con un estudio de los climas de la Tierra. Trad. Hendrichs Pérez PR. Fondo de Cultura Económica, México.

LABOURIAU, L.G. 1983. A germinação das sementes. Série de Biologia. Monografia 24. Secretaria Geral da Organização dos Estados Americanos - OEA, Washington.
MANHÃES, M.A., ASSIS, L.C.S. \& CASTRO, R.M. 2003. Frugivoria e dispersão de sementes de Miconia urophylla (Melastomataceae) por aves em um fragmento de Mata Atlântica secundária em Juiz de Fora, Minas Gerais, Brasil. Ararajuba 11:173-180.

MARTINS, R.L. \& OLIVEIRA, P.E. 2003. RAPD evidence for apomixis and clonal populations in Eriotheca (Bombacaceae). Plant Biology 5:338-340.

NETER, J., WASSERMAN, W. \& KUTNER, M.H. 1985. Applied linear statistical models: regression, analysis of variance and experimental designs. Richard D. Irwin, Illiniois.

OFIR, M. \& KIGEL, J. 2003. Variation in onset of summer dormancy and flowering capacity along an aridity gradient in Poa bulbosa L., a geophytic perennial grass. Annals of Botany 91:391-400.

OLIVEIRA-FILHO, A.T., CURI, N., VILELA, E.A. \& CARVALHO, D.A. 1998. Effects of canopy gaps, topography, and soils on the distribution of woody species in a Central Brazilian Deciduous Dry Forest. Biotropica 30:362-375.

PEREIRA-DINIZ, S.G. 2003. Ecofisiologia da germinação de sementes de Clidemia hirta (L.) D. Don (Melastomataceae). Dissertação de mestrado, Universidade Federal de Uberlândia, Uberlândia.

PEREIRA-DINIZ, S.G. \& RANAL, M.A. 2006. Germinable soil seed bank of a gallery forest in Brazilian Cerrado. Plant Ecology 183:337-348.

QUEIROZ, M.H. 1983. Influência da luz na germinação de Miconia cinnamomifolia (DC.) Naudin - jacatirão-açu. Insula 13:29-37.

RANAL, M.A. \& SANTANA, D.G. 2006. How and why to measure the germination process? Revista Brasileira de Botânica 29:1-11.

RIBEIRO, J.F. \& WALTER, B.M.T. 1998. Fitofisionomias do bioma cerrado. In Cerrado: ambiente e flora (S.M. Sano \& S.P. Almeida, eds.). Embrapa, Planaltina, p.89-166.

ROACH, D.A. \& WULFF, R.D. 1987. Maternal effects in plants. Annual Review of Ecology and Systematics 18:209-235.

ROMERO, R. \& MARTINS, A.B. 2002. Melastomataceae do Parque Nacional da Serra da Canastra, Minas Gerais, Brasil. Revista Brasileira de Botânica 25:19-24.

SANTANA, D.G. \& RANAL, M.A. 2004. Análise da germinação: um enfoque estatístico. Editora UnB, Brasília.

SANTANA, D.G. \& RANAL, M.A. 2006. Linear correlation in the experimental design models applied on seed germination. Seed Science and Technology 34:241-247.

SANTOS, M.L. 2003. Florística e biologia reprodutiva de espécies de Melastomataceae do Parque Estadual da Serra de Caldas Novas e Parque Estadual dos Pirineus, Goiás. Tese de doutorado, Universidade de Brasília, Brasília.

SNEDECOR, G.W. \& COCHRAN, W.G. 1989. Statistical methods. 8th ed. Iowa State University Press, Ames. 
TWENEY, J. \& MOGIE, M. 1999. The relationship between achene weight, embryo weight and germination in Taraxacum apomicts. Annals of Botany 83:45-50.

VÁLIO, I.F.M. \& SCARPA, F.M. 2001. Germination of seeds of tropical pioneer species under controlled and natural conditions. Revista Brasileira de Botânica 24:79-84.

VENABLE, D.L. 1984. Using intraspecific variation to study the ecological sgnificance and evolution of plant lifehistories. In Perspectives on plant population ecology (R. Dirzo \& J. Sarukhán, eds.). Sunderland. Sinauer Associates, Massachusetts, p.166-187.

VIEIRA, I.C.G., GALVÃO, N. \& ROSA, N.A. 1996. Caracterização morfológica de frutos e germinação de sementes de espécies arbóreas nativas da Amazônia. Museu Paraense Emílio Goeldi, Série Botânica 12: 271-288.
WATANABE, T. \& OSAKI, M. 2001. Influence of aluminium and phosphorus on growth and xylem sap composition in Melastoma malabathricum L. Plant and Soil 237: 63-70.

WATANABE, T., JANSEN, S. \& OSAK, M. 2005. The beneficial effect of aluminium and the role of citrate in $\mathrm{Al}$ accumulation in Melastoma malabathricum. New Phytologist 165:773-780.

WEEB, L.B. 1954. Aluminium accumulation in the Australian - New Guinea flora. Australian Journal of Botany 2:176196.

WERKER, E. 1997. Seed anatomy. Gebrüder Borntraeger, Berlin.

ZAIA, J.E. \& TAKAKI, M. 1998. Estudo da germinação de sementes de espécies arbóreas pioneiras: Tibouchina pulchra Cogn. e Tibouchina granulosa Cogn. (Melastomataceae). Acta Botanica Brasilica 12:221-229. 
